\title{
CUSTOMER SATISFACTION AT AN ONLINE STORE IN SOUTH AFRICA
}

\author{
Prof Vinessa Naidoo' ORCID: 0000-0002-2358-5588 \\ Mr KG Botsi² ORCID: 0000-0002-7083-8971
}

\begin{abstract}
:
Online shopping has become a common way in which retail businesses are conducted across most parts of the world. South African (SA) retailers such as Takealot, Makro, and Spree added this function to their existing operations. However, the survival of SA online stores is compromised by the competitive activities set by international players, including Amazon, eBay, and Google. Online stores such as Nine West and Mango have closed amidst poor financial performance. The adoption of a customer-centred approach is among the strategies that SA online stores can take to remain competitive. It is against this background that this study sought to assess customers' perceptions of electronic service quality and to determine its influence on customer satisfaction and customer behavioural intentions.

A quantitative descriptive approach methodology, using a questionnaire structured by SurveyMonkey, was employed to collect data from a sample of 300 online customers from the online store in SA. SPSS V24 was employed to conduct descriptive and multivariate analyses, including factor analysis and correlations analyses. The results indicated that the respondents were not fully satisfied with the service quality of the online store regarding efficiency, system availability, fulfilment, privacy, responsiveness, compensation, and contact. It was also found that electronic service quality sub-constructs have a positive effect on customer satisfaction. Furthermore, the researcher found that customer satisfaction had a positive effect on customer behavioural intentions. Several implications for practice were provided to the management of online stores to facilitate improvement in their operations.
\end{abstract}

\section{Introduction and Background}

Online shopping refers to the sale and purchase of products via the internet (Rudansky-Kloppers, 2014). Rachamim (2014) noted that there are approximately 24 million online stores worldwide. SA retailers such as Takealot, Makro, and Spree also offer online services in addition to their existing operations. However, the survival of SA online stores is threatened by the competitiveness of international players such as Amazon, eBay, and Google (My Broadband, 2017). According to Brand-Jonker (2017), the online clothing stores Nine West and Mango closed, due to poor financial performance. The adoption of a customer-centred approach is one strategy, among others, that SA online stores can take to remain competitive and relevant. Kotler and Keller (2016) argued that the assessment of customers' perceptions of electronic service quality and its influence on customer satisfaction, is one of the recommended strategies that online stores can employ. According to Kotler and Keller (2016), a good experience of online shopping is facilitated by electronic service quality. Parasuraman, Zeithaml, and Malhotra (2005) proposed the constructs of electronic service quality to include efficiency, fulfilment, system availability, privacy, responsiveness, compensation, and contact. Researchers in marketing and consumer behaviour such as Kotler and Keller (2016), bemoan that most retailers are reluctant to consider customers' perceptions on electronic service delivery. Failure

'Tshwane University of Technology

${ }^{2}$ Tshwane University of Technology 
to adopt a customer-centred approach results in customer dissatisfaction, reduced sales, dwindling profits, and ultimately the closure of the business.

Customer satisfaction is defined by Zeithaml, Bitner, and Gremler (2009) as a positive attitude that a customer builds upon receiving a service or product. Customer satisfaction occurs when the service delivery matches their expectations, while customer dissatisfaction occurs when service delivery is lower than these expectations. Customer behavioural intention is a reaction that follows after a retail experience (Kotler \& Keller, 2016). Customer satisfaction results in positive customer behavioural intentions, including customer referral and repeated purchase, while customer dissatisfaction results in negative customer behavioural intentions. Therefore, it is against this background that this study proposes to assess customers' perceptions of electronic service quality in a SA online store.

\section{Conceptual Framework}

This study is based on the concepts of electronic service quality, customer satisfaction, and customer behavioural intentions. It is therefore conceptualised that electronic service quality factors (efficiency, fulfilment, system availability, privacy, responsiveness, compensation, and contact) (Parasuraman et al. 2005) have a statistically significant effect on customer satisfaction, which in turn affects customer behavioural intentions.

The objectives of this study are:

1. To assess customers' perceptions of the electronic service quality of an online store in SA.

2. To determine the effect of electronic service quality on customer satisfaction.

3. To establish the effect of customer satisfaction on customer behavioural intentions.

To address the objectives of the study, the research question is: To what extent does electronic service quality influence customer satisfaction?

The research hypotheses were also formulated as:

H1: Perceived efficiency has a statistically significant effect on customer satisfaction.

H2: Perceived system availability has a statistically significant effect on customer satisfaction.

H3: Perceived fulfilment has a statistically significant effect on customer satisfaction.

H4: Perceived privacy has a statistically significant effect on customer satisfaction.

H5: Perceived responsiveness has a statistically significant effect on customer satisfaction.

H6: Perceived compensation has a statistically significant effect on customer satisfaction.

H7: Perceived contact has a statistically significant effect on customer satisfaction.

H8: Perceived customer satisfaction has a statistically significant effect on customer behavioural intentions.

\section{LITERATURE REVIEW \\ Definition of Online Shopping}

Online shopping is a digital-driven process through which customers search for products or services and purchase them through internet connected devices (Rudansky-Kloppers, 2014). Online shopping has four distinct stages that include the storefront, the shopping cart, the payment process, and the order fulfilment. Vazifehdust, Ameleh, Esmaeilpour, and Khadang (2014) divided online shopping into different components, namely navigation, information search, transactions, and interactions with customers. Rudansky-Kloppers (2014) stated that online shopping allows customers to search for products and services from anywhere in the world, order the selected products and services, decide on the delivery option, and make a payment. The process of online shopping is illustrated in Figure 1.

The online shopping process illustrated by Rukuni (2018) shows that the first step occurs when a customer approaches the online store via the internet, which takes customers to the storefront (Chellapalli and Kumar, 2016), i.e. the first page of the store's website. The storefront provides customers with information such as product and service features, prices, and delivery terms (Akkucuk \& Teuman, 2016). The second step in the online shopping process involves the shopping cart and selection of products or services (Al-Nasser, Yusoff \& Islam, 2016), and it provides customers with an option to park products or services intended for future purchase, through a wish-list facility. 


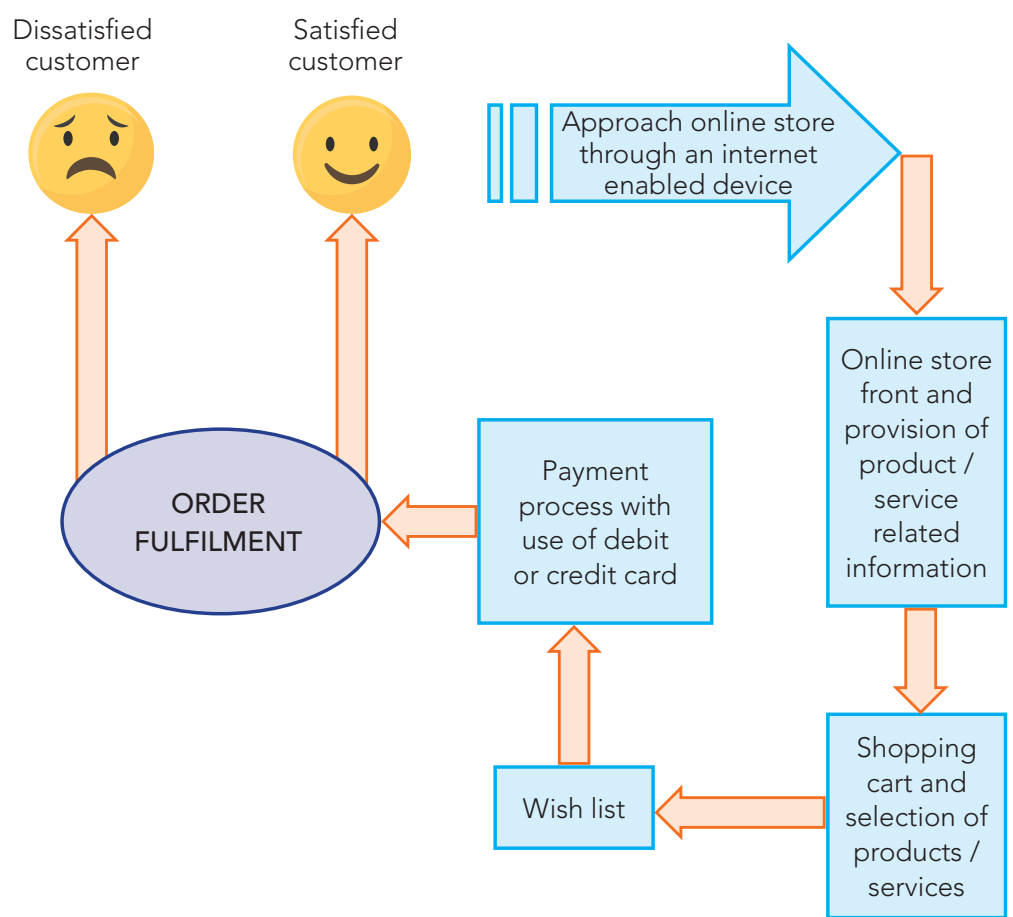

Figure 1: Online shopping operational process

Source: Rukuni (2018)

Ardakani, Ardakani, and Ardakani (2015) indicated that the third step is when a customer intends to purchase the product or service immediately. They then proceed to process the payment by means of a debit or credit card. The fourth step is comprised of an order fulfilment (Rukuni, 2018). At this stage, the online store should deliver the purchased products or services to the address supplied by the customer. The end of the online shopping process is associated with the customer's experience and attitude (Aren, Guzel, Kabadayi \& Alkan, 2013). Figure 1 shows that customers can either experience satisfaction or dissatisfaction. This stage does not usually get attention from online stores that do not understand the importance of pre-transactional, transactional, and post-transactional customer satisfaction (Parasuraman et al. 2005). The failure to take the various stages of customer satisfaction into consideration, results in a loss of competitive advantage.

\section{Online Shopping in Different Parts of the World}

Online shopping developed all over the world. Statistics supplied by Business Tech (2015) showed that online shopping is practised through Europe, Oceania, South America, North America, and Africa. Oceania is the continent with the highest online shopping usage response rate, with New Zealand (95\% participating consumers) that is the most active in this process (Kwarteng \& Pilik, 2018). The highest usage in Europe has been identified in Finland (97\% participating consumers). The service is just as popular in Canada and the USA ( $97 \%$ and $87 \%$ participation). The highest usage for South America was registered in Argentina, at 75\%. Figure 2 displays this usage in more detail.

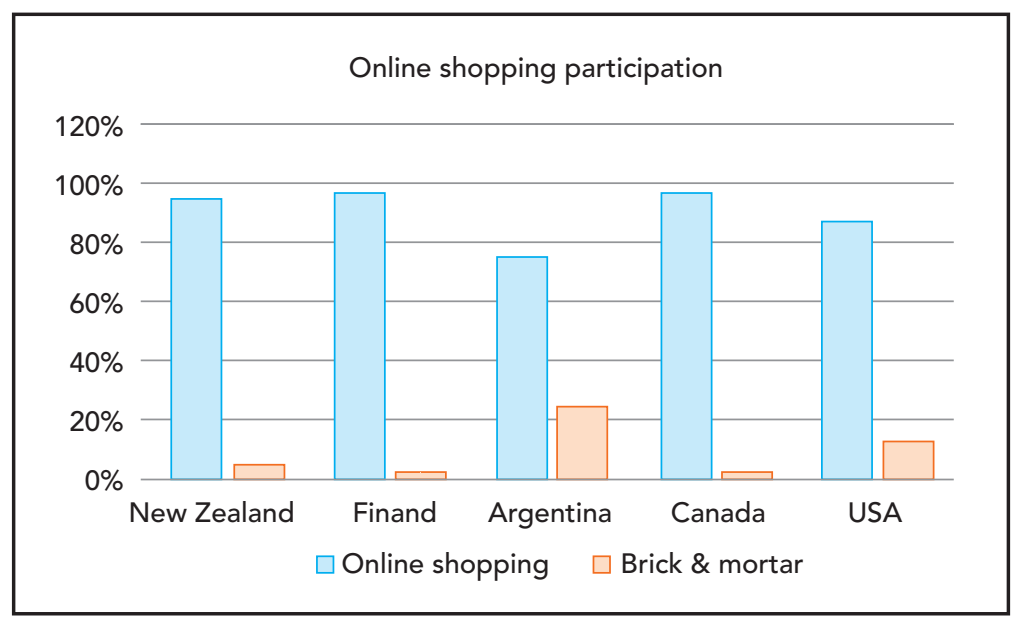

Figure 2: Online shopping participation Source: Kwarteng and Pilik (2018) 
On the African continent, Nigeria has the greatest online shopping activity followed by South Africa and Kenya (Kwarteng \& Pilik, 2018). Among the BRICS nations (Brazil, Russia, India, China, and South Africa), SA lags behind Brazil, Russia and China in terms of online shopping transactions, with a $0.9 \%$ purchase rate, followed by India with a $0.7 \%$ transaction rate. Brazil accounts for $11 \%$, China for $10.7 \%$ and Russia for $4.2 \%$.

\section{Competitive Pressure in the South African Online Shopping Industry}

According to Rudansky-Kloppers (2014) and Vazifehdust et al. (2014), it can be accepted that online shopping is susceptible to competition. This view is further supported by the fact that customers can search for products and services from anywhere in the world. International online stores therefore have the opportunity to tap into world markets, including the SA market, which means that they are in direct competition with online stores in SA. Rachamim (2014) reported between 12 and 24 million online stores in the world, most of which are situated in developed countries, especially the USA (Goldstuck, 2013). Due to the strong competition, only 650000 are able to generate an income of $\$ 100000$ or more (Goko, 2014).

\section{Customer Satisfaction}

Customer satisfaction is an attitude that customers experience upon receiving a service or a product. It as an expression of pleasure or displeasure by a customer after the use of a product or service (Kotler \& Keller; 2016; Robbins, Judge, Odendaal \& Roodt, 2016). Zeithaml et al. (2009) expressed customer satisfaction as an attitude that is gained from pre-transaction, transaction, and post-transaction, indicating that it is perpetuated through a customer's experience with the online store.

The term 'pre-transaction' refers to the interaction between the customer and online store before a purchase has been made (Khare \& Rakesh, 2011). It generally begins with the accessibility of the online store's website, where customers expect to find information regarding products and services. Meeting such expectations will lead to pre-transaction customer satisfaction. During the transactional stage, customer satisfaction is influenced by the selection process as well as the payment procedure (Gupta, lyer \& Weisskirch, 2010). The actual delivery of the product or service is also an important aspect of customer satisfaction during this phase. Post-transaction activities involve contact from the store after the product or service has been delivered.

\section{Theories of Customer Satisfaction}

Theories regarding customer satisfaction are critical for understanding the concept. It also validates the importance of customer satisfaction in online stores. Three main theories have been identified, namely the dissonance theory, the contrast theory, and the expectancy disconfirmation theory (Carter, 2010; Shala \& Balaj, 2016).

The dissonance theory refers to a state in which a customer has inconsistent thoughts and beliefs about the purchase or service experience (Shala \& Balaj, 2016). Robbins et al. (2016) described it as the condition in which a customer experiences a cognitive disagreement when receiving a lower service than expected. Cognitive dissonance is a sign that a customer is unhappy with the purchase experience and that expectations have not been met. The online shopping store should aim towards reducing or removing cognitive dissonance among its customers.

According to Robbins et al. (2016), the contrast theory portrays an exaggerated reaction from customers when the delivered product or service did not meet their expectations. Unhappy customers tend to underrate the delivery (Frederick, 2013), but when the product or service delivered meets customer expectation, it does not receive a positive exaggeration. In the contrast theory, the exaggeration of a service occurs in the negative direction.

The expectancy disconfirmation theory argues that customers have specific expectations before a service is received (Kumari \& Rani, 2011; Rahman, Khan \& Haque, 2012). Customers, therefore, make use of their pre-conceived expectations to assess a service. When expectations are not met, dissatisfaction occurs. When expectations are met or exceeded, satisfaction occurs. In other words, the expectancy disconfirmation theory is based on a logical premise of how customers react to service delivery as influenced by their previous expectations. Consequently, this theory is widely used to present customer satisfaction studies.

\section{The Importance of Customer Satisfaction and Behavioural Intentions}

The realisation of customer satisfaction by online stores is essential for maintaining a competitive edge. Customer satisfaction generally leads to repeated purchase, long-term customer relationships, positive word of mouth, expansion of the market, and an increase in sales and profits (Marimon, Vidgen, Barnes \& Cristobal, 
2010). Consequently, customer satisfaction is critical for the survival of online stores in a competitive environment (Moharrer, Tahayori \& Sadeghian, 2013).

According to Robbins et al. (2016), customers are attracted by good service delivery, which could result in repeated purchases. Customers tend to develop an extended purchase pattern with online stores that can satisfy their needs and that understand their requirements (Mozaheb, Alamolhodaei \& Ardakani, 2015).

Online stores should focus on long-term customer relationship building, as this will result in multiple purchase actions. Nagra and Gopal (2013) found that customers prefer to conduct business with an online store that values a good relationship. Pandey, Barik, and Soni (2015) argued that successful organisations focus on maintaining good customer relationships, since it is more expensive to get new customers than to maintain the existing ones.

Positive word of mouth is by far the most effective way to attract more customers to an organisation. According to Phang, Kankanhalli, Ramakrrishnan, and Raman (2010), satisfied customers spread good word about their experiences to friends and relatives. Online stores should use this cost-effective opportunity to induce positive customer intentions. Customer satisfaction is reflected through financial performance. Online stores generate more sales due to customer satisfaction. Sharma and Lijuan (2015) suggested that satisfied customers prefer staying with the same online store for future purchases.

\section{Factors Affecting Customer Satisfaction and Electronic Service Quality}

Electronic service quality is one of the main indicators for customer satisfaction (Parasuraman et al., 2005). To understand how electronic service quality influences customer satisfaction, different models were put in place to explain factors that customers consider when transactions are carried out. Models for electronic service quality are founded on the SERVqual model (Parasuraman, Zeithaml \& Berry, 1988), which is generally known as a tool for assessing service industries. The SERVqual model expresses that services are measured through constructs such as tangibility, empathy, reliability, assurance, and responsibility. Electronic service quality is explained by models such as PIRQUAL, E-S-QUAL and E-RECS-S-QUAL, LEE and LIN, WEBQUAL, SITEQUAL, and SYZMANSKI and HISE. Table 1 illustrates factors that are regarded important for customer satisfaction in online stores.

Table 1: Electronic Service Quality Constructs

\begin{tabular}{|c|c|}
\hline MODELS & CONSTRUCTS \\
\hline PIRQUAL & $\begin{array}{l}\text { Web store functionality, product attribute description, ownership conditions, delivery, customer } \\
\text { service and security. }\end{array}$ \\
\hline $\begin{array}{l}\text { E-S-QUAL and } \\
\text { E-RECS-S-QUAL }\end{array}$ & Efficiency, fulfilment, system availability, privacy, responsiveness, compensation and contact. \\
\hline LEE and LIN & Website design, reliability, trust effect and personalisation. \\
\hline WEBQUAL & Usability, design, information, trust and empathy. \\
\hline SITEQUAL & Ease of use, aesthetic design, processing speed and security. \\
\hline $\begin{array}{l}\text { SYZMANSKI and } \\
\text { HISE }\end{array}$ & Online convenience, merchandising, site design and financial security. \\
\hline PIRQUAL & $\begin{array}{l}\text { Web store functionality, product attribute description, ownership conditions, delivery, customer } \\
\text { service and security. }\end{array}$ \\
\hline $\begin{array}{l}\text { E-S-QUAL and } \\
\text { E-RECS-S-QUAL }\end{array}$ & Efficiency, fulfilment, system availability, privacy, responsiveness, compensation and contact. \\
\hline LEE and LIN & Website design, reliability, trust effect and personalisation. \\
\hline WEBQUAL & Usability, design, information, trust and empathy. \\
\hline SITEQUAL & Ease of use, aesthetic design, processing speed and security. \\
\hline $\begin{array}{l}\text { SYZMANSKI and } \\
\text { HISE }\end{array}$ & Online convenience, merchandising, site design and financial security. \\
\hline
\end{tabular}

Source: Francis and White (2005); Lee and Lin (2005), and Parasuraman et al. (2005) 
- The efficiency of an online store is expressed through its website. According to Kotler and Keller (2016), the website is regarded as efficient when customers can find what they are looking for. The information should be arranged in such a way that customers can navigate easily to gather the information that they need to make a purchase. The website pages should also load quickly and customers should be able to transact without difficulties (Akkucuk \& Teuman, 2016).

- Fulfilment is important to maintain customer satisfaction in online shopping operations (Prashar, Vijay \& Parsad, 2016). The online store should be in a position to deliver the products or services within the specified time frame and it should have the needed facilities, such as transportation, to fulfil the customer's needs. According to Moharrer et al. (2013), the speed at which the online store delivers the purchased products and services is critical in maintaining customer satisfaction.

- System availability assesses the ability of the website to remain online. The website should always be active (Panda \& Swar, 2016) and should launch and run immediately when customers are making use of it (Sharma \& Lijuan, 2015). It is also important that the website does not crash or freeze when customers are browsing on it.

- During online shopping transactions, there is a trade of information between customers and the online store authorities, such as personal details and credit card information. Therefore, customers expect the store to treat the details in a confidential and secure way (Nagra \& Gopal, 2013). Customers need to be assured that their information will not be shared with unauthorised parties (Frederick, 2013).

- According to Mokhlis (2012), responsiveness refers to the online store's ability to respond to the needs of its customers and should be paramount for online stores. Williams and Naumann (2011) claimed that the handling of product returns should be included in this feature. The online store is also expected to offer meaningful guarantees for products and services that are sold to its customers.

- The element of compensation best addresses the post-transactional service for an online store. Customers expect online stores to compensate them for failure to provide the products or service as promised. According to Kotler and Keller (2016), the online store should be in a position to compensate its customers for problems that it creates, for example, when ordered products and services arrive late. The online shopping store should also practise the courtesy of collecting products that customers want to return.

- The provision of contact details creates the human element for the online store (Kotler \& Keller, 2016) and could lead to customer satisfaction. Shala and Balaj (2016) explained that contact is established through contact numbers and people to speak to when customers call the online store. Marimon et al. (2010) also argued that contact enhances customer satisfaction, since it is able to bridge the gap between customers and the online store.

\section{Empirical Studies and the Development of the Research Gap}

The concept of customer satisfaction and electronic service quality attracted the attention of several researchers (Carter, 2010; Akkucuk \& Teuman, 2016; Panda \& Swar, 2016; Shala \& Balaj, 2016). Chen, Tsai, Hsu and Lee (2013) conducted a study on Chinese online stores and found electronic service quality to be influenced by the usability, responsiveness, visual significance, reliability, and information quality. They did not, however, test the efficiency of the online store as an important factor for electronic service quality and customer satisfaction.

Vazifehdust et al. (2014) carried out a study in the Iranian banks' online systems. They established that the critical factors for electronic service quality are usability, website design, reliability, privacy, and responsiveness. This study, however, did not consider fulfilment as an important factor for electronic service quality. It is noteworthy that the Middle East differs significantly from the African countries.

The study carried out by Rudansky-Kloppers (2014) found that convenience and delivery time were the most important reasons for buying online. This finding is contradictory to Ardakani et al. (2015), who found that security has the greatest impact on customer satisfaction in online store operations. However, Rudansky-Kloppers (2014) and Ardakani et al. (2015) did not test the significance of privacy towards customer satisfaction.

Fichardt (2015), Sasikala (2013), as well as Ganguli and Roy (2011), realised that innovative security and continuous encryption have a positive effect on customer satisfaction and they found responsiveness to have a lower effect on customer satisfaction. Sasikala (2013) carried out the study in India, where the environment is quite different from that of SA. 
Byamba and Chang (2012) carried out a study on three airlines, namely Atlanta, Emirates, and Hainan, and found that customer satisfaction occurred due to usability, website design, payment security, interactivity, and information quality. Akkuk and Teuman (2016) found that customer satisfaction occurs as a result of payment security and interactivity. The conducted studies presented certain shortfalls that motivate the current study in the South African setting.

\section{Research Methodology}

The study employed the positivism research paradigm, which was pursued through a quantitative descriptive research design to assess customers' perceptions of the electronic service quality of a SA online store and determine how it influences customer satisfaction and behavioural intentions. A Survey Monkey questionnaire was selected as the data collection technique, adapted from Parasuraman et al. (2005). The convenience sampling strategy was used for selecting the sample of participants. Objective 1 was measured using descriptive analysis in the form of mean and standard deviation. Inferential data analyses involved the use of reliability and validity tests, as well as correlation and regression analysis. The online store offered a database of approximately 5000 customers. A minimum sample size of 300 customers participated in the study. Raosoft (2014) was utilised to determine the minimum sample size with a 5\% margin of error and $95 \%$ confidence interval. A convenience sampling strategy was employed to select the study sample and it was deemed appropriate, based on its cost-effectiveness and timeous nature when collecting data from a homogeneous study population.

\section{The Research Paradigm and Justification}

Positivism research paradigm involves gaining knowledge through understanding respondents' experience (Saunders, Lewis \& Thornhill, 2012; Stangor, 2011). In this study the customers' experience of online shopping was critical to understand the phenomenon and it was important in providing detail about the store's electronic service quality and customer satisfaction. It was appropriate to make use of the positivism paradigm, since the researcher aimed at gaining knowledge through understanding the respondents' experiences (Saunders et al., 2012; Tavakol \& Dennick, 2011), and also due to its ability to produce results that are quantifiable and observable (Blumberg, Cooper \& Schindler, 2011).

The nature of the objectives namely, to establish the effect of electronic service quality on customer satisfaction, as well as to determine the effect of customer satisfaction on customer behavioural intentions, required the use of a structured data collection tool (Industrial Research Institute, 2010; Malhotra, 2010). The quantitative research methodology was therefore employed, since it enabled the use of a structured research questionnaire. Maintaining the objectivity of the study, required the use of a method that does not alter or manipulate the research environment. Questionnaires are suitable for maintaining the research environment (Malhotra \& Birks, 2007; Hair, Bush \& Ortinau, 2006).

\section{Population of Interest}

The total population of the study was the 5000 customers on the data base of a SA online store. A sample of 300 customers were selected through the convenience sampling strategy, to take part in the study. The researcher distributed questionnaires to 320 customers through Survey Monkey. Of the 320 questionnaires distributed, 300 were returned fully completed, resulting in a 94\% response rate. The other 20 questionnaires had missing responses and could not be statistically analysed. This higher response rate can be attributed to the mode of questionnaire distribution, which is known to yield an average response rate of $76.9 \%$ (Field, 2009).

\section{Data Collection}

A structured questionnaire adapted from Parasuraman et al. (2005) consisted of two sections addressing the demographic information of the respondents and the variables relating to the objectives of the study.

In order to answer the formulated research question, dependent and independent constructs were used (Field, 2009). Table 2 indicates that there were two dependent variables, each with four questions, and seven independent variables with a total of 26 items. These variables were measured on a 5 -point Likert Scale, with $1=$ strongly agree and $5=$ strongly disagree. 
Table 2: Variables Investigated in this Study

\begin{tabular}{|l|c|c|c|c|}
\hline \multicolumn{1}{|c|}{ VARIABLE } & TYPE OF VARIABLE & MEASUREMENT & NUMBER OF ITEMS & HYPOTHESES \\
\hline Efficiency & Independent & Continuous & 5 & $\mathrm{H}_{1}$ \\
\hline System availability & Independent & Continuous & 4 & $\mathrm{H}_{2}$ \\
\hline Fulfilment & Independent & Continuous & 4 & $\mathrm{H}_{3}$ \\
\hline Privacy & Independent & Continuous & 3 & $\mathrm{H}_{4}$ \\
\hline Responsiveness & Independent & Continuous & 4 & $\mathrm{H}_{5}$ \\
\hline Compensation & Independent & Continuous & 3 & $\mathrm{H}_{6}$ \\
\hline $\begin{array}{l}\text { Contact } \\
\text { Customer satisfaction }\end{array}$ & Dependent & Continuous & 3 & $\mathrm{H}_{7}$ \\
\hline $\begin{array}{l}\text { Customer behavioural } \\
\text { intentions }\end{array}$ & Dependent & Continuous & 4 & $\mathrm{H}_{8}$ \\
\hline $\begin{array}{l}\text { Total continuous } \\
\text { variables }\end{array}$ & & & 34 & $\mathrm{H}_{9}$ \\
\hline
\end{tabular}

Data analysis for this study was conducted through the application of SPSS version 24 . The following techniques were used for analysis, based on recommendations by Field (2009):

- Descriptive statistics was used to describe the sample's demographic profile and customers' perception of electronic service quality.

- Factor analysis was used to reduce variables into smaller groups of latent variables and to test validity.

- Reliability analysis was done through Cronbach's alpha to assess the measure of internal consistency of the measurement scales.

- Correlation tests were used to determine whether there is a relationship between electronic service quality, customer satisfaction, and customer behavioural intentions.

- Regression analysis was used to test the formulated hypotheses.

\section{Ethical Considerations}

Meeting ethical considerations is important for all academic studies and it ensures that the rights of respondents are protected throughout. The main ethical issue encountered in this research was that of consent. The researcher obtained consent from participants, reported all results honestly, and ensured that the research conducted did not harm the participants in any way.

\section{Data Analysis and Discussion of the Results Biographic Characteristics of the Sample}

The biographic profiling of the sampled customers showed that there were more male respondents at $51 \%$. Most respondents, at $32 \%$ (95), were in the age group of 36 to 45 years. The distribution across the four main races were fairly even, with Black respondents in the majority at $38 \%$ (114). The White and Coloured respondents accounted for 21\% (62) each, while there were 20\% (61) Indian respondents. Most participants held a diploma (38\%), followed closely by degrees and post graduate qualifications at $28 \%$ and $27 \%$ respectively.

\section{Customers' Perceptions of Electronic Service Quality at the Sub-Construct Level}

The perceptions of the respondents were assessed on seven sub-constructs of electronic service quality. These subconstructs included efficiency, system availability, fulfilment, privacy, responsiveness, compensation, and contact. Compensation had the highest negative customer perceptions, with a mean value of 2.57 . This was followed by efficiency, with a mean value of 2.42, responsiveness at 2.38 , system availability at 2.36 , contact at 2.29, and fulfilment and privacy at 2.18 each. The perceptions that customers have of the seven sub-constructs of electronic service quality, are provided in Figure 3. 


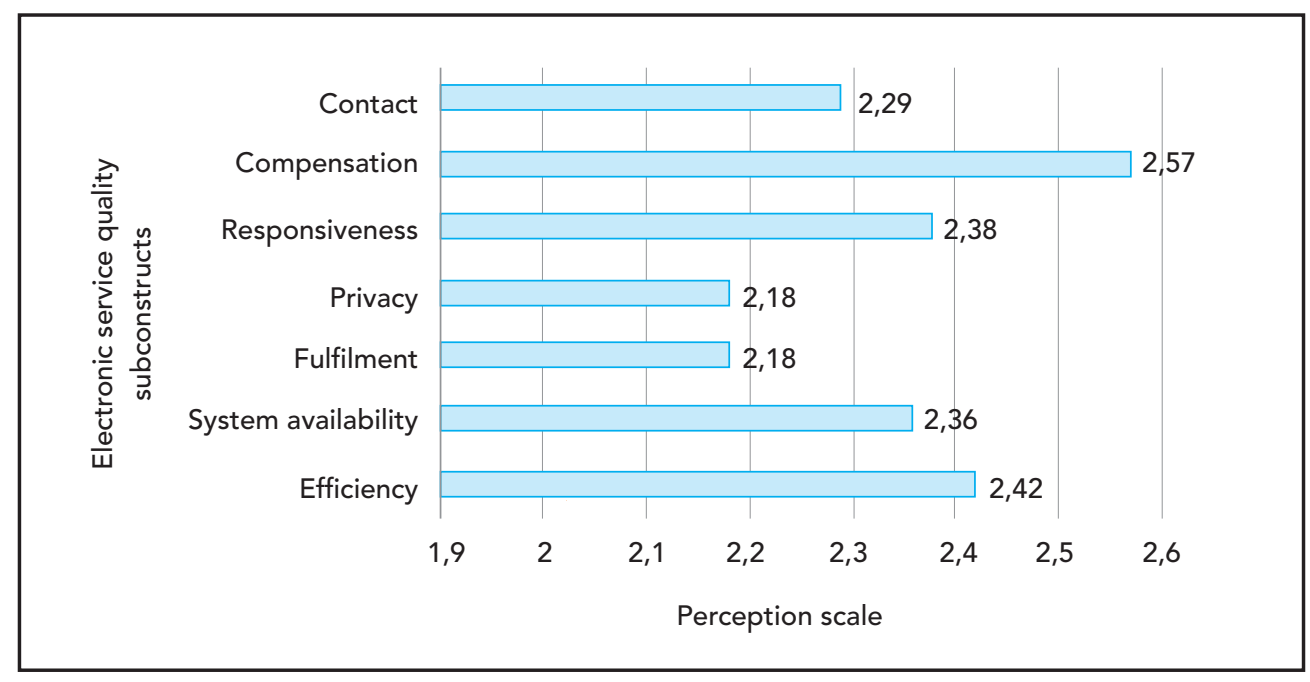

Figure 3: Customers' Perceptions of Electronic Service Quality Sub-Constructs

\section{Customers' Perceptions of Electronic Service Quality at the Item Level}

Customers' perceptions of electronic service quality were also assessed on all 26 items employed to measure the sub-constructs. It was found that customers had negative perceptions on all the items that were employed to measure electronic service quality. The ten items with the worst negative perceptions were:

- They pick up items I want to return from my home or business (3.22);

- They offer the ability to speak to a live person if there is a problem (2.55);

- The site offers a meaningful guarantee (2.48);

- They tell me what to do if my transaction is not processed (2.45);

- Pages at the site do not freeze after I enter my order information (2.49);

- Information at the site is well organised (2.4);

- It is easy to get anywhere on the site (2.52);

- The site makes it easy to find what I need (2.49);

- The site enables me to complete a transaction quickly (2.39); and

- The site does not crash (2.35).

\section{Customers' Perceptions of Customer Satisfaction}

Customer satisfaction was measured by four items. It was found that participants had negative perceptions of all the items. The mean value for the four items was closely related between 2.34 and 2.84 .

\section{Customers' Perceptions of Customer Behavioural Intentions}

The four items presented to measure these perceptions were also met with negative results, with mean values above 2.0. From the results it was established that it was very unlikely for participants to recommend the online store to others, with a mean value of 3.01. The mean values of the other three items were very similar, at 2.86, 2.87 and 2.87 , respectively.

\section{Validity and Reliability}

Validity and reliability were assessed to improve the creditability of this study. Reliability was tested using Cronbach's alpha and the validity of the questionnaire was tested using factor analysis. Cronbach alpha resulted in 0.87 with one sub-construct, namely compensation, not reaching the required threshold, with $\alpha=0.66$. The results of the Cronbach alpha for the other eight sub-constructs varied from 0.76 to 0.88 , indicating reliability.

In this study, 34 items were assessed for construct validity and 31 items proved to be valid. However, it was found that three items for compensation could not reach the minimum required threshold. Based on the results, compensation was excluded for further analysis such as correlation and regression. $\mathrm{H} 6$ which states that compensation has a statistically significant effect on customer satisfaction, is thus rejected. 


\section{Correlation Analyses}

In order to address Objectives 2 and 3, correlation analysis was employed. Correlation analysis is suitable for measuring the relationship between two or more constructs. To assess the strength of the relationships between constructs, the Pearson coefficient (R-value) and the probability coefficient (P-value) were considered (Saunders et al., 2012:234). The R-value ranges from -1 to 1 , where -1 indicates a perfect negative relationship, 1 a perfect positive relationship, and 0 no relationship. The $\mathrm{P}$-value assesses the significance of the $\mathrm{R}$-value results. For statistically significant results $P \leq 0.05$. The results for correlation analysis among electronic service quality constructs, customer satisfaction, and customer behavioural intentions, are provided in Table 3.

Table 3 Correlation Analysis among Electronic Service Quality Sub-Constructs, Customer Satisfaction and Customer Behavioural Intentions

\begin{tabular}{|c|c|c|c|c|c|c|c|}
\hline & \multicolumn{7}{|c|}{ FACTORS } \\
\hline & 1 & 2 & 3 & 4 & 5 & 6 & 7 \\
\hline Efficiency & 1 & & & & & & \\
\hline System availability & $.61^{\star}$ & 1 & & & & & \\
\hline Fulfilment & $.48^{*}$ & $.48^{*}$ & 1 & & & & \\
\hline Privacy & $.48^{\star}$ & $.51 *$ & $.61^{*}$ & 1 & & & \\
\hline Responsiveness & $.68^{\star}$ & $.64^{*}$ & $.47^{\star}$ & $.49^{\star}$ & 1 & & \\
\hline Contact & $.52^{\star}$ & $.43^{\star}$ & $.29 *$ & $.38^{\star}$ & $.48^{\star}$ & 1 & \\
\hline Customer satisfaction & $.45^{\star}$ & $.40^{\star}$ & $.26^{\star}$ & $.37^{\star}$ & $.42^{\star}$ & $.53^{\star}$ & 1 \\
\hline $\begin{array}{l}\text { Customer behavioural } \\
\text { intentions }\end{array}$ & $.45^{\star}$ & $.39 *$ & $.14^{\star}$ & $.29 *$ & $.46^{*}$ & $.57^{\star}$ & $.42^{\star}$ \\
\hline
\end{tabular}

$\star=\mathrm{p}<.001$

The results on correlation analysis provide evidence that a moderate positive correlation exists between electronic service quality sub-constructs, customer satisfaction, and customer behavioural intentions. It was appropriate to proceed with regression analysis.

\section{Regression Analysis}

The SPSS software was also used to perform regression analysis in order to test the formulated hypotheses. The important coefficients for regression analysis include the beta ( $\beta$ ), P-value (significance) and the R2. The $\beta$-coefficient reflects the R-value, which measures the strength and direction of a relationship between constructs. The $P$-value measures the significance of the relationship, while the R2 -coefficient is the explanatory power of an independent construct on the dependent variables.

\section{- Hypothesis 1}

Hypothesis 1 states that perceived efficiency has a statistically significant effect on customer satisfaction. Based on the regression analysis findings ( $r$-value $=0.45 ; p$-value $=0.000$ ), hypothesis 1 is accepted at 0.00 significance level. This study therefore found that perceived efficiency has a statistically significant positive effect on customer satisfaction.

\section{- Hypothesis 2}

Hypothesis 2 stipulates that perceived system availability has a statistically significant effect on customer satisfaction. The findings on regression analysis ( $r$-value $=0.40 ; p$-value $=0.000$ ) indicate that system availability has a statistically significant positive effect on customer satisfaction. This finding therefore confirms that system availability has a statistically significant positive effect on customer satisfaction. 


\section{- Hypothesis 3}

Hypothesis 3 was formulated as perceived fulfilment and has a statistically significant effect on customer satisfaction. The findings on regression analysis ( $r$-value $=0.26$; $p$-value $=0.000$ ) show that perceived fulfilment has a statistically significant positive effect on customer satisfaction. It is therefore confirmed that perceived fulfilment has a statistically significant effect on customer satisfaction.

\section{- Hypothesis 4}

Hypothesis 4 states that perceived privacy has a statistically significant effect on customer satisfaction. Based on the regression analysis findings ( $r$-value $=0.37 ; p$-value $=0.000$ ), Hypothesis 4 is accepted at 0.00 significance level. This study therefore found that perceived privacy has a statistically significant positive effect on customer satisfaction.

\section{- Hypothesis 5}

Hypothesis 5 stipulates that perceived responsiveness has a statistically significant effect on customer satisfaction. The findings on regression analysis ( $r$-value $=0.37$; $p$-value $=0.000$ ) indicate that perceived responsiveness has a statistically significant positive effect on customer satisfaction. This finding therefore confirms that perceived responsiveness has a statistically significant positive effect on customer satisfaction.

\section{- Hypothesis 7}

Hypothesis 7 was formulated as perceived contact and has a statistically significant effect on customer satisfaction. The findings on regression analysis ( $r$-value $=0.53 ; p$-value $=0.000$ ) show that perceived contact has a statistically significant positive effect on customer satisfaction. It is therefore confirmed that perceived contact has a statistically significant effect on customer satisfaction.

\section{- Hypothesis 8}

Hypothesis 8 states that perceived customer satisfaction has a statistically significant effect on customer behavioural intentions. Based on the regression analysis findings ( $r$-value $=0.42 ; p$-value $=0.000$ ), Hypothesis 8 is accepted at 0.00 significance level. This study therefore found that perceived customer satisfaction has a statistically significant positive effect on customer behavioural intentions.

The findings also showed that perceived contact has the highest explanatory power on customer satisfaction than any other electronic service quality sub-constructs. This is evidenced by $\mathrm{R} 2=0.28$, which was higher than those of other electronic service quality sub-constructs. Perceived efficiency had the second highest explanatory power on customer satisfaction with $\mathrm{R} 2=0.20$ perceived responsiveness, followed with $\mathrm{R} 2=0.18$, perceived system availability with $R 2=0.16$, perceived privacy with $R 2=0.14$, and perceived fulfilment with $R 2=0.07$.

\section{Conclusions and Recommendations}

\section{Conclusion on Objective 1}

The first objective in this study sought to assess customers' perceptions on electronic service quality of the online store in South Africa. It can be concluded that the participants had negative perceptions of the electronic service quality sub-constructs and all the items measuring electronic service quality. These included efficiency, system availability, fulfilment, privacy, responsiveness, compensation, and contact. Compensation was found to have the highest negative customers' perceptions, followed by efficiency, responsiveness, system availability, contact, fulfilment, and privacy.

\section{Conclusion on Objective 2}

The second objective sought to determine the effect of electronic service quality on customer satisfaction. Based on the findings, it can be concluded that electronic service quality sub-constructs have an effect on customer satisfaction. This conclusion also answers the research question: To what extent does electronic service quality influence customer satisfaction? It is concluded that electronic service quality sub-constructs influence customer satisfaction at varying levels. The sub-construct that has the most influence on customer satisfaction was contact, followed closely by efficiency, system availability, and privacy. The least influencing sub-construct was fulfilment. 


\section{Conclusion on Objective 3}

Objective 3 sought to establish the effect of customer satisfaction on customer behavioural intentions. Based on the findings, it is concluded that customer satisfaction has an effect on customer behavioural intentions.

\section{Summary of the Findings}

The findings from the descriptive statistics show that the respondents had negative perceptions on electronic service quality of an online store in South Africa. The results from correlation and regression analysis also showed a positive relationship between the electronic service quality sub-constructs, customer satisfaction, and customer behavioural intentions. Table 4 summarises the hypotheses and major results.

Table 4 A Summary of the Hypotheses and Major Results

\begin{tabular}{|l|l|l|}
\hline & \multicolumn{1}{|c|}{ HYPOTHESES } & \multicolumn{1}{c|}{ RESULTS } \\
\hline$H_{1}$ & $\begin{array}{l}\text { Perceived efficiency has a statistically significant effect on } \\
\text { customer satisfaction. }\end{array}$ & $\begin{array}{l}\text { Accept } \\
p<0.001, r=0.45, \\
\beta=0.45\end{array}$ \\
\hline$H_{2}$ & $\begin{array}{l}\text { Perceived system availability has a statistically significant effect } \\
\text { on customer satisfaction. }\end{array}$ & $\begin{array}{l}\text { Accept } \\
p<0.001, r=0.40, \\
\beta=0.40\end{array}$ \\
\hline$H_{3}$ & $\begin{array}{l}\text { Perceived fulfilment has a statistically significant effect on } \\
\text { customer satisfaction. }\end{array}$ & $\begin{array}{l}\text { Accept } \\
p<0.001, r=0.26, \\
\beta=0.26\end{array}$ \\
\hline$H_{4}$ & $\begin{array}{l}\text { Perceived privacy has a statistically significant effect on } \\
\text { customer satisfaction. }\end{array}$ & $\begin{array}{l}\text { Accept } \\
p<0.001, r=0.37, \\
\beta=0.37\end{array}$ \\
\hline$H_{5}$ & $\begin{array}{l}\text { Perceived responsiveness has a statistically significant effect on } \\
\text { customer satisfaction. }\end{array}$ & $\begin{array}{l}\text { Accept } \\
p<0.001, r=0.42, \\
\beta=0.42\end{array}$ \\
\hline$H_{7}$ & $\begin{array}{l}\text { Perceived contact has a statistically significant effect on } \\
\text { customer satisfaction. }\end{array}$ & $\begin{array}{l}\text { Accept } \\
p<0.001, r=0.53, \\
\beta=0.53\end{array}$ \\
\hline$H_{8}$ & $\begin{array}{l}\text { Perceived customer satisfaction has a statistically significant } \\
\text { effect on customer behavioural intentions. }\end{array}$ & $\begin{array}{l}\text { Accept } \\
p<0.001, r=0.42, \\
\beta=0.42\end{array}$ \\
\hline
\end{tabular}

\section{Implications for Theory}

This study implies that customers have negative perceptions of electronic service quality sub-constructs that include efficiency, system availability, fulfilment, privacy, responsiveness, and contact. This finding, however, is different from the findings in Shala and Balaj's (2016) and Carter's (2010) studies, which provided evidence that customers had positive perceptions of electronic service quality. This study also implies the existence of a relationship among electronic service quality, customer satisfaction, and customer behavioural intentions. It is implied that efficiency has a statistically significant positive effect on customer satisfaction. This confirms the findings in the study by Akkucuk and Teuman (2016), indicating that efficiency is an important sub-construct of electronic service quality, that has a relationship with customer satisfaction. Chen et al. (2013) pointed out that efficiency alone cannot determine customer satisfaction.

It is also implied that system availability has a statistically significant positive effect on customer satisfaction. This finding is in line with Vazifehdust et al. (2014), yet opposing Ardakani et al. (2015), who found that system availability is not a suitable measure for customer satisfaction. This study also implies that fulfilment has a statistically significant effect on customer satisfaction. Ardakani et al. (2015) and Rudansky-Kloppers (2014) reported similar results. Furthermore, it is implied that privacy has a statistically significant effect on customer satisfaction. The finding confirms the results in Fichardt's (2015) and Sasikala's (2013) studies, which found privacy to be an important influence on customer satisfaction. Chen et al. (2013), however, found that privacy alone is not sufficient in the determination of customer satisfaction.

Further implications of this study show that responsiveness has a statistically significant effect on customer 
satisfaction. This is in line with Vazifehdust et al. (2014), who also found that perceived responsiveness has a statistically significant effect, yet Ardakani et al. (2015) found that perceived responsiveness is not a suitable measure for customer satisfaction. It is also confirmed that contact has a statistically significant effect on customer satisfaction, supporting the findings of Ardakani et al. (2015) and Rudansky-Kloppers (2014). It is further implied that customer satisfaction has a statistically significant effect on customer behavioural intentions. The finding also confirms the findings in Akkucuk and Teuman's (2016) study, which found that perceived customer satisfaction is an important construct that influences customer behavioural intentions.

\section{Implications for Practice}

This study found that customers had negative perceptions of electronic service quality of the online store in South Africa, and more specifically on efficiency, system availability, fulfilment, privacy, responsiveness, compensation, and contact. It is based on this conclusion that this study provides several recommendations.

- The online store should promptly pick up products that are due for returns.

It is critical that the online store addresses product returns to the satisfaction of customers. They should constantly be in touch with their customers to enable a quick response on requests related to product returns. A policy should be developed with regard to the cycle time of collecting products for return from the customer and the replacement of those items. The response to these requests should be quick to ensure customer satisfaction.

- The online store should have a live person to speak to customers.

This could be done via telephone or email. The presence of a person to talk to at the online store, brings a human attribute to the store, and it could lead to customer satisfaction when queries and complaints receive appropriate responses.

- The online store should offer a meaningful product and service guarantee.

Customers need the assurance that faulty products can be returned or replaced. The terms and conditions of the guarantee should be clearly specified in order for customers to fully understand the aspects covered by the online store.

- The online store should keep customers informed on the status of their transactions.

The online store should create and maintain a great level of transparency regarding its transactions. Customers should be able to tell how much they are getting billed and when they will receive their products. This feature could be available on the store's webpage.

- The online store should ensure that pages on the website do not freeze.

This could be achieved by employing the services of a capable IT department that enforces the smooth functioning of the online shopping system. The online store should also keep in touch with the ever-changing technological environment.

- The online store should ensure that the website is well organised and user-friendly.

The website should be well organised and should have the relevant information. It is further important that information is updated regularly and that negotiation on the website is easy and sensible. It is essential that the website can be easily displayed on a variation of devices such as smartphones.

- Ensure that the site enable customers to complete a transaction quickly.

It is therefore important for the online store to make use of effective software that enables the system to run fast.

\section{Limitations of the Study}

A limitation identified in this study relates to the data collection method. Since this study was quantitative in nature, the researcher employed a questionnaire. This side-lined other data- collection methods, such as interviews, which could have allowed respondents to provide their own perspective. Another limitation is the study sample that was limited to a single online store. The views of customers of other online stores were not considered. Hence, the findings in this study do not reflect the opinions of all online store customers in SA. An additional limitation is that the study made use of a cross-sectional research approach, which prohibits the investigation of changes in 
customers' perceptions. Lastly, only seven sub-constructs of electronic service quality were employed, but there are numerous sub-constructs that could have been considered to fully understand electronic service quality and the perceptions of the customers.

\section{Conclusion}

The objectives of this study were threefold. It was concluded that customers had a negative perception of electronic service quality sub-constructs that included efficiency, system availability, fulfilment, privacy, responsiveness, compensation, and contact. It was also concluded that electronic service quality sub-constructs have a positive effect on customer satisfaction. Furthermore, the researcher found that customer satisfaction has a positive effect on customer behavioural intentions. Several implications for practice have been provided to the management of the online store to facilitate improvement in their operations.

\section{Acknowledgements:}

We would like to sincerely thank the Tshwane University of Technology for making this study possible.

\section{References}

Akkucuk, U. \& Teuman, B. (2016). Assessing service quality in online banking services. Problems and Perspectives in Management, 14(2):183-191.

Al-Nasser, M., Yusoff, R.Z. \& Islam, R. (2016). Mediating effect of e-service quality perceptions on attitude and trust toward online shopping. International Business Management, 10(3):228-240.

Ardakani, S.H.H., Ardakani, M.S. \& Ardakani, M.F. (2015). A study about customer satisfaction of e-service quality of point of sale (POS). Academic Journal of Economic Studies, 1(2):120-130.

Aren, S., Guzel, M., Kabadayi, E. \& Alkan, L. (2013). Factors affecting repurchase intention to shop at the same website. Procedia-Social and Behavioural Science, 99:536-544.

Blumberg, B., Cooper, D.R. \& Schindler, P.S. (2011). Business research methods. London: McGraw-Hill.

Brand-Jonker, N. (2017). Battle of the brands as popular clothing stores shut down in SA.

Fin24. [Online]. Available from: https://www.fin24.com/Companies/Retail/battle-of-the-brands-as-popular-clothingstores-shut-down-in-sa-20170714 [Accessed: 08/06/2018].

Business Tech. (2015). How much South African spend online. Business Tech. [Online]. Available from: http:// businesstech.co.za/news/internet/97565/how-much-south-africans-spend-online/ [Accessed: 01/03/2018].

Byamba, B. \& Chang, K. (2012). The Influence Factors of Online Purchase on Customer Satisfaction in Mongolian Airlines. Graduate Institute of International Business. Taiwan: National Dong-Hwa University.

Carter, T. (2010). The challenge of managers keeping customers. International Management Review, 6(2):20-27.

Chellapalli, T. \& Kumar, D.V.S. (2016). Electronic payment systems: Role of demographics. Journal of Indian Management, 41-52.

Chen, M.H., Tsai, K.M., Hsu, Y.C. \& Lee, K.Y. (2013). E-service quality impact on online customer's perceived value and loyalty. China-USA Business Review, 12(5):473-485.

Fichardt, C. (2015). Is 2015 the year for online shopping in South Africa? [Online]. Available from: http://ventureburn. com/2015/01/2015-year-oline-shopping-south-africa/ [Accessed: 04/06/2018].

Field, A. (2009). Discovering statistics using SPSS. 3rd ed. Thousand Oaks: Sage Publications.

Frederick, D. (2013). Social contrast theory should be abandoned. Rationality, Markets and Morals, 4:178-190.

Francis, J.E. \& White, L. (2005). What Internet shoppers expect, beyond the web site [Online]. Available from: http://130.195.95.71:8081/WWW/ANZMAC2001/anzmac/AUTHORS/pdfs/Francis.pdf> [Accessed: 02/07/2018].

Ganguli, S. \& Roy, S.K. (2011). Generic technology-based service quality dimensions in banking: Impact on customer satisfaction and loyalty. International Journal of Bank Marketing, 29(2):168-189.

Goko, C. (2014). Online shopping market grows in South Africa. [Online]. Available from: http://www.bdlive.co.za/ business/retail/2013/02/04/online-shopping-market-grows-in-south-africa [Accessed: 26/08/2018].

Goldstuck, A. (2013). Media future: The fastest growing categories of online sales in South Africa [Online]. Available 
from: http://www.marklives.com/2013/07/media-future-the-fastest-growing-categories-of-online-sales-in-southafrica/ [Accessed: 21/08/2018].

Gupta, B., lyer, L.S. \& Weisskirch, R.S. (2010). Facilitating global e-commerce: A comparison of consumers' willingness to disclose personal information online in the US and in India. Journal of Electronic Commerce Research, 11(1):41-53.

Hair, J.F., Bush, R.P. \& Ortinau, D.J. (2006). Marketing research within a changing environment. 3rd ed. New York: McGraw-Hill Irwin.

Industrial Research Institute. (2010). Research management. Michigan.

Khare, A. \& Rakesh, S. (2011). Antecedents of online shopping behaviour in India: An examination. Journal of Internet Commerce, 10(4):227-244.

Kotler, P. \& Keller, K.L. (2016). Marketing management. 15th ed. New York: Pearson.

Kumari, H.V. \& Rani, S.S. (2011). Customer perception of service quality in the retail banking sector. European Journal of Business \& Management, 3(3):299-306.

Kwarteng, M.A. \& Pilik, M. (2018). Exploring consumers' propensity for online shopping in a developing country: A demographic perspective. International Journal of Entrepreneurial Knowledge, 1(4):90-103.

Lee, G. \& Lin, H. (2005). Customer perceptions of e-service quality in online shopping. International Journal of Retail \& Distribution Management, 33(2):161-176.

Malhotra, N. (2010). Marketing Research: An Applied Orientation. 6th ed. Upper Saddle River, NJ: Pearson.

Malhotra, N. \& Birks, D. (2007). Marketing Research: An Applied Approach. 3rd European Ed. Harlow: Pearson Education.

Marimon, F., Vidgen, R., Barnes, S. \& Cristobal, E. (2010). Purchasing behaviour in an online supermarket, the applicability of E-S-Qual, The Market Research Society, 52:111-129.

Moharrer, M., Tahayori, H. \& Sadeghian, A. (2013). Drivers of customer satisfaction in online tourism- the case of European countries. Middle-East Journal of Scientific Research, 13(9):1172-1179.

Mokhlis, S. (2012). The influence of service quality on satisfaction: A gender comparison. Public Administration Research, 1(1):103-112.

Mozaheb, A., Alamolhodaei, S.M.A. \& Ardakani, F.M. (2015). A study of influencing factors of customer relate ship management on business performance in small and medium business (SMEs). International Journal of Academic Research in Accounting, Finance \& Management Sciences, 5(2):42-52.

My Broadband. (2017). Best online shop in South Africa [Online]. Available from: https://mybroadband.co.za/ news/business/233411-best-online-shop-in-south-africa.html [Accessed: 04/04/2018].

Nagra, G. \& Gopal, R. (2013). A study of factors affecting on online shopping behaviour of consumers. International Journal of Scientific \& Research Publications, 3(6):2250-3153.

Panda, R. \& Swar, B.N. (2016). Electronic retailing: A review of determinants of online shopping intentions in India. Indian Journal of Science \& Technology, 9(15):1-6.

Pandey, B.B., Barik, P. \& Soni, V. (2015). Online shopping catching up fast with the trend-Chhattisgarh context. International Journal of Research in Commerce \& Management, 6(4):53-57.

Parasuraman, A., Zeithaml, V.A. \& Berry, L.L. (1988). A multi-item scale for measuring consumers' perceptions of quality. Journal of Retailing, 64(1):12-40.

Parasuraman, A., Zeithaml, V.A. \& Malhotra, A. (2005). E-S-QUAL a multiple-item scale for assessing electronic service quality. Journal of Service Research, 7(10):1-21.

Phang, C.W., Kankanhalli, A., Ramakrrishnan, K. \& Raman, K. (2010). Customers' preference of online store visit strategies: An investigation of demographic variables. European Journal of Information Systems, 19:344-358.

Prashar, S., Vijay, T.S. \& Parsad, C. (2016). Segmenting online shoppers: A study of consumers' web portal selection motivations for e-shopping. Asian Academic of Management Journal, 21(1):27-46.

Rachamim, O. (2014). How many online stores are there in the world? Digital commerce 360

[Online]. Available from: https://www.digitalcommerce360.com/2014/12/04/how-many-online-stores-are-thereworld/ [Accessed: 08/06/2018]. 
Rahman, M.S., Khan, A.H. \& Haque, M. (2012). A conceptual study on the relationship between service quality towards customer satisfaction: SERVqual and Gronroos's service quality model perspective. Journal of Asian Social Science, 8(13):201-210.

Raosoft. (2014). Sample size calculator. [Online] Available from: http://www.raosoft.com/samplesize.html [Accessed: 20/05/2018].

Robbins, S.P., Judge, T.A., Odendaal, A. \& Roodt, G. (2016). Organisational Behaviour: Global and South African perspectives. 3rd ed. Cape Town: Pearson.

Rudansky-Kloppers, S. (2014). Investigating factors influencing customer online buying satisfaction in Gauteng, South Africa. International Business \& Economics Research Journal, 13(5):1187-1198.

Rukuni, T.F. (2015). Service quality and student satisfaction at a private college in the City of Tshwane. MBA dissertation, Pretoria, Tshwane University of Technology.

Rukuni, T.F. (2018). Electronic service quality and customer satisfaction in South African online stores: The role of psychographics on perceptions. PhD in Management, Cape Town, University of the Western Cape.

Sasikala, D. (2013). Impact of demographics on service quality, customer satisfaction and loyalty in the Indian banking in Vellore district. Asia Pacific Journal of Marketing \& Management Review, 2(6):102-116.

Saunders, M., Lewis, P. \& Thornhill, P. (2012). Research Methods for Business Students. 5th ed. England: Pearson Education Limited.

Shala, A. \& Balaj, D. (2016). Electronic service quality and its impact on building brand loyalty in the apparelretailing industry. Review of Innovation \& Competitiveness, 2(2):5-30.

Sharma, G. \& Lijuan, W. (2015). The effects of online service quality of e-commerce websites on user satisfaction. The Electronic Library, 33(3):468-485.

Stangor, C. (2011). Research methods for the behavioural sciences. 4th ed. Wadsworth.

Tavakol, M. \& Dennick, R. (2011). Making sense of Cronbach's alpha. International Journal of Medical Education, 2:53-55.

Vazifehdust, H., Ameleh, K.N., Esmaeilpour, F. \& Khadang, M. (2014). The investigation of relationship between e-service quality, perceived value, satisfaction and loyalty: A study of Iranian Banks. Asian Journal of Research in Marketing, 3(2):156-167.

Williams, P. \& Naumann, E. (2011). Customer satisfaction and business performance: A firm-level analysis. Journal of Services Marketing, 25:20-32.

Zeithaml, V.A., Bitner, M.J. \& Gremler, D.D. (2009). Services marketing: Integrating customer focus across the firm. New York: McGraw. 